\title{
Ethno-veterinary practices by the people Lepcha Primitive Tribe living in the Dzongu Tribal Reserve Area (DTRA) in North- Sikkim, India
}

\author{
S. R. Lepcha \\ Department of Science \& Technology, Govt. of India and Sikkim State Council of Science \& Technology, \\ Deorali, Gangtok, Sikkim, India \\ E-mail: drsrlepcha@gmail.com
}

[Received 19.05.2020; Revised 23.06.2020; Accepted 25.06.2020; Published 30.06.2020]

\begin{abstract}
People of Lepcha primitive tribe mostly live in Dzongu Tribal Reserve Area (DTRA) situated in the North district of North-east Indian state of Sikkim. DTRA was officially demarcated as Lepcha Reserve area by the former Maharaja of Sikkim and as per article 30.69 (Sikkim's old laws). The practice of age-old traditional methods for the treatment of livestock is still prevalent in far-flung villages within the Reserve. Traditional folk healers, Bongthing or Moandhok (priest or herbalist) has created and inherited such heritage-knowledge through innumerable generations since the time immemorial. The present exploration of potential local traditional ethno-veterinary medicines (EVM), ingredients and basic formulations in 09 prominent villages in the fringes of DTRA during 2011 to 2017 and consulted 120 folk-practitioners of veterinary medicines. The survey recognized 13 main livestock diseases prevalent inside the study-area, vi\%: diarrhoea, dysentery, cough, foot-mouth diseases, skin disease, delayed expulsion of the placenta etc. The survey also recorded the uses of 27 species of plants from 24 families and few non-biological materials for the preparation of ethno-medicines by the folk-veterinary practitioners in DTRA area.
\end{abstract}

Key words: Ethno-veterinary, EVM, Livestock, Traditional Knowledge, Heritage, Dzongu, Lepchas

\section{INTRODUCTION}

Documentation of traditional usages of plants is an emerging field of interest for the researchers in discoveries of new drugs (Pushpangadan \& Dan 2011; Pushpangadan et al. 2018). The use of plants by different communities as ethno-medicines in their primary health care is overwhelming. The tribal people are the primary inhabitants of natural habitats, hold tremendous amount of traditional knowledge on the uses of various biotic resources. Indian subcontinent is inhabited by 53.8 million tribal people belonging to 550 tribal communities that constitutes $7.5 \%$ of population. They inhabit in around 5000 forest villages in the country located in varied geographical and climatic zones (Das \& Pandey 2007). The plethora of knowledge on plants used in medicine is maximum in the Indian Himalayan region (Samant \& Dhar 1997; Samant $e t$ al. 1998). The East Himalayan Indian state Sikkim is widely known as a center of biodiversity and bio-resources and has been reported to house over 550 species of medicinally important plants (Tamang \& Lepcha 2001; Sharma \& Sharma 2010).

Pradhan and Badola in 2008 mentioned that exploratory researches on ethno-medicinal use of plants are not sufficiently taken up targeting the remotely located tribal areas of Sikkim. Only few sporadic scientific reports on ethno-medicines in Sikkim have been published so far, including, Biswas (1956), Bennet (1983), Krishna \& Singh (1987), Shrivastava \& Kapaki (1990), Pandey (1991), Kumar et al. (1994), Rai \& Sharma (1994), Sinha \& Chauhan (1997), Tamang \& Lepcha (2002), Gurung (2003), Maity et al. (2003a, b), Maity \& Rai (2003), Jha et al. (2006), 
Sharma \& Sharma (2010), Pradhan \& Badhola (2008), Lepcha \& Das 2011, and Yonzon et al. (2012).

Dzongu Tribal Reserved Area (DTRA) located in north Sikkim is mostly inhabited by Lepcha primitive tribe. Dzongu was once under the possession of Laso kaji during the regime of Phuntsog Namgyal, and was the $9^{\text {th }}$ district of greater Sikkim (Morris 1938). The DTRA was officially demarcated as Lepcha Reserved Area by the Maharaja of Sikkim (as per the article 30.69 of Sikkim's old laws). These reserves are set up particularly for safeguarding the tribe's culture and preventing it from economic exploitation and such other disabilities those can result from the intrusion of non-lepcha people from outside and can affect the tribe's identity of aboriginality (Fonning 1987). Farming of large cardamom is one of the main stays of the local people for over the last 100 years. In fact, when cardamom introduced in Dzongu is not known. Jhon Morris in his book, Living with Lepchas (1938) mentioned that "I have never seen it in such parts of eastern Nepal as I have visited". The book mentioned, "It is believed in Jongu that cardamoms were introduced from Nepal, though I understand that the plant is not cultivated in that country." The keenest observer-traveler cum botanist Sir J.D Hooker makes no mention of it in his Himalayan Journal. Recently, cardamom production is being seriously affected by diseases that put lot of pressure on the Lepcha people (Bhasin 2011). The fragmentation of the forest covers in DTRA was on increase during 1977 to 2000, and the reverse has been noticed during 2000 to 2009 and that is due to loss of cardamom fields. it has been decreased, due to the changes in area covered by large cardamom at the fields by diseases (Agura 2014).

Where as, apart from the domestication of crops such as large cardomom, maize, barleys, buckwheat, maize etc., livestock rearing is an important main stay for the people of DTRA since time immemorial. According to Gorer (1938) and Morris (1938), the animals were reared more for socio-cultural reasons than for the economic benefit as all their rituals and ceremonies were accompanied by the animal sacrifice. However, at the present juncture, apart from that, animal and animal-products constitute a significant source of secondary income for local Lepchas; major domestic animals are cows, bulls, goats, pigs, fowl, dogs, cats and few Yaks in Upper Dzongu. (Sharma 2013). Prior to the enforcement of state government's initiative in banning on grazing in the state in 1998, the farmers / families of DTRA do have many herds of livestock spreading from Lum Lungtyang to Rimpi river in extreme north, resulting a large numbers of cattle have been reduced in past two decades. Forest department (2010). As the rearing of livestock plays an important role in social, religious and economic sustenance of the people in DTRA, the cattle owners and local Moandok still uphold the culture of traditional healing system against the cattle's ailments. The Lepchas of DTRA annually performs ceremonies to mollify the supernatural spirit of " Zampala / Zomola Ruum (God of animals )" to seek fertility enhancement, in taming spread of the diseases in animals (Sharma 2013).

Traditional folk veterinary medicine or ethno-veterinary medicine involves the use of domestic knowledge, belief, practices and skills pertaining to healthcare and management of human, animals and birds (McCorkle 1986). In our country, modern veterinary care reaches only $20 \%$ of livestock owners resulting in a loss of approximately Rs. 50 billion annually due to diseases in livestock. (Nair et al. 2011). Therefore, EVM is an integration of the local knowledge and a procedures created by local people for purpose of preserving health and welfare of the productive animals (Köhler-Rollefson \& Bräunig 1998; Punniamurthy 2010; Das \& Triparthy 2009). Rearing of livestock and poultry plays an important role not only in the economy of these people but also associated with their social and religious life (Sharma \& Sharma 2010). The potential plants which his being used in EVM needs to be studied carefully and with 


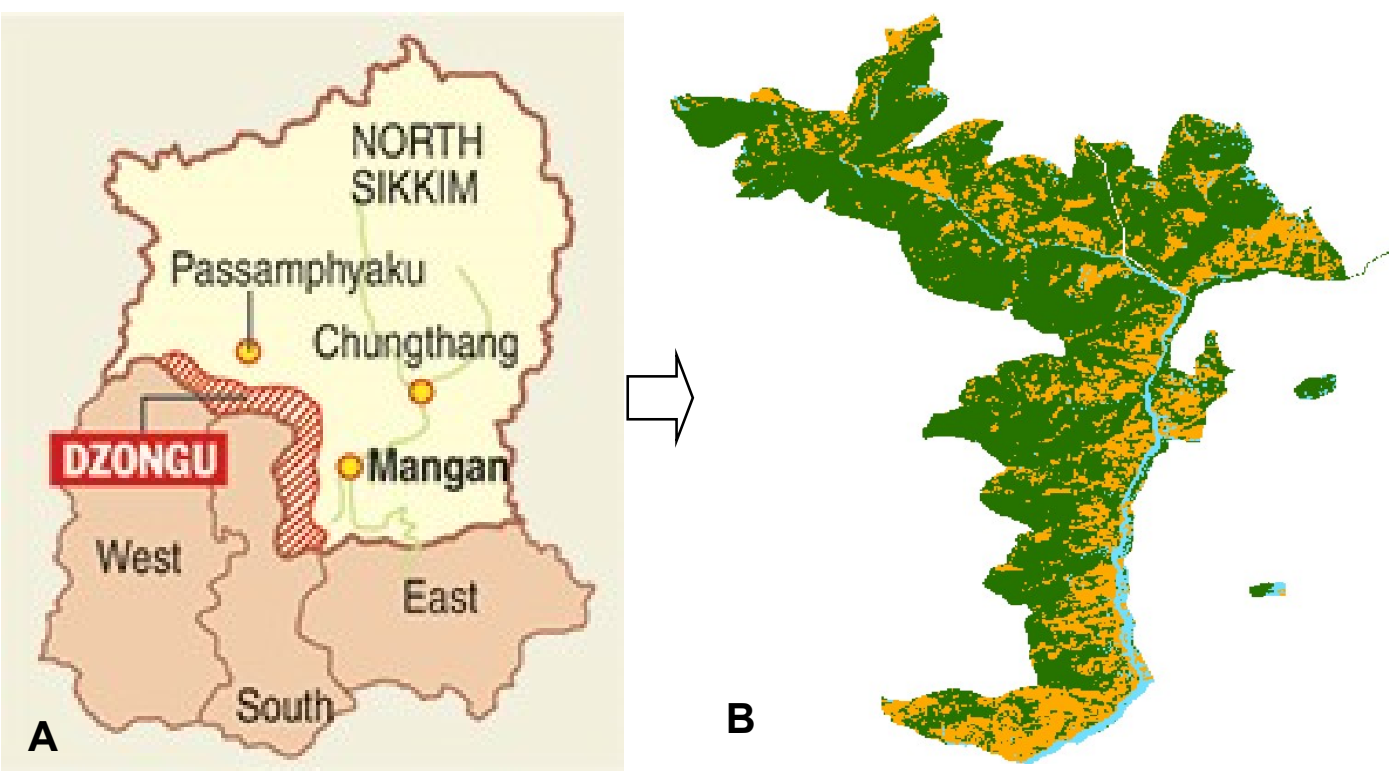

Figure 1: Location of map of DTRA: A. Location of Dzongu in Sikkim; B. Forest cover and drainage in the area (not to the scale) [Source: Agura 2014]

systematic approach (Lepcha 2011). In animal health care, the use of plants as supporting therapy in preventive purposes or as a complete therapy has a huge potential regardless whether it is the question of individual or combined plant medicinal preparations which act synergistically (Davidovic et al. 2011). Whereas, rapid changes of communities across the world, coupled with poor storage format of ethno-veterinary knowledge inherited from generation to generation by word of mouth, has greatly endangered its survival and sustainability into the future (Ahmed et al. 2016; Balaji \& Chakravarthi 2010).

There is no records of any extensive exploration on ethno-veterinary traditions including the formulations in Sikkim in general and DTRA in particular apart from few studies made by Bharati \& Sharma (2010). However, Sharma (2012) recorded 37 species of herbal plants being used against 15 livestock ailments.

The Lepchas of DTRA consider ethno-veterinary as thamchang'g Nyeat moan and they have been practicing it since the time immemorial. This age old methods of treatment of EVM is still in practice in the far-flung villages of DTRA but are yet to record till date. Such knowledge was generated and maintained by practice only through numerous generations by the local folk healers, Bongthing (local priest) and Moandoak (the knowledge owners of herbals plants). The folk healers are recognized as equivalent to the doctor in their settlements. They proved their efficiency through several cases of successful treatment of using one or more plants. However, doses and the mode of administration may vary from place to place and community wise (Lepcha et al. 2013). So, the livestock owners in DTRA mostly depend on such alternative medicines for the treatment of their cattle as medicines are locally available, easily accessible and are much cheaper than that of modern drugs.

Hence, understanding the gap in our recorded knowledge, a study was conducted to explore the potential ethno-veterinary knowledge stored in traditional ways in different farflung but important fringe areas of DTRA during 2011 to 2016. 


\section{Study area:}

DTRA is "T" shaped strip of hilly terrains, valleys and steep mountains with the total geographical area of $78 \mathrm{sq} \mathrm{km}$, located at coordinates ranging in between $27^{\circ} 28^{\prime}-27^{\circ} 38^{\prime} \mathrm{N}$ latitudes and $88^{\circ} 23^{\prime}-88^{\circ} 38^{\prime}$ E longitudes with altitude ranges in between 700 to $6000 \mathrm{~m}$ amsl. The area is bounded to the South by river Ung-Rungfap (adjoining to Lum village), North by Kishong lake, East by River Teesta and west is bounded by Kanchenjunga Biophere Reserved (KBR) (Figure 1). The DTRA is a home of the Lepchas or Rongs, an indigenous tribe of Sikkim Himalaya. With the approximate population of c.10,000. The DTRA is administratively divided into 7 blocks and 35 wards. The entire area is again divided into upper Dzongu and lower Dzongu with 7 Gram Panchayat Units. DTRA is under the administrative control of Sub-Divisional Administration and Block Development Administration offices located at Passindang, Upper Dzongu. Rungyong and Rungnyu are two major rivers and their tributaries forms the drainage network. The area receives about 3000 - $3500 \mathrm{~mm}$ of precipitation annually.

\section{METHODOLOGY}

Based on appropriate format, an extensive survey for EVM were conducted at DTRA area in North Sikkim during the years 2011 - 2016. Most of the remote and interior villages and the administrative blocks including Lum, Luntyang, Gor, Taryang, Sangdong, Hee Gyathang, Lingdong, Barfok, Passingdang, Lingthem, Lingdem, Tingvong, Ship-Gyer and at Naga Namgor, under DTRA were thoroughly explored and investigated. The name of the places were identified with due consultation of Gram Panchayats, local folk healers, Block Development Officer and other heard man of the projected area. A total of 150 livestock owners were consulted, interviewed based on a structured questionnaire. Few other local non-tribal groups, herdsmen from age group of 25 to 90 were also consulted. The key informants, however, were traditional folk healers (Moandhok, Pawo, Mun, Bongthing), herdsmen, livestock owners, farmers and other elderly persons.

The first author being a Lepcha and a resident of DTRA, it was very much easier to interact with informant in their own Lepcha-language. Interviews and discussions were documented through tape-recorder and video camera in addition to writing notes. Interviews were conducted mainly in the field and the useful plants were recognized by the informants themselves. Voucher specimens of all such plants were collected and recorded in the field-note-book. Cross-checking was liberally done among different unrelated informants.

The collected voucher specimens were later processed into mounted herbarium-sheets following Jain and Rao (1977) and were identified using available published literature such including Hooker (1872 - 1897), Grierson and Long (1983 - 2001), and Noltie (1994, 2000), and were matched at the BSHC Herbarium. For updated nomenclature and family delimitation www.plantsoftheworldonline.org has been consulted. A set of voucher specimens has been deposited at Sikkim State Council of Science \& Technology under Department of Science \& Technology, Deorali, Gangtok, Sikkim.

\section{RESULT}

During the survey, a total of 159 ethno-medicinal plant practitioners have been consulted who looks after the health care of domesticated animals in Dzongu. The result of the studies on ethno-veterinary medicines used by the people of Lepcha tribal community living in DTRA has been presented below in tabular form (Table 1). 
Table 1: Ethno-veterinary medicinal formulations of Dzongu Tribal Reserve Area (DTRA) [Abbreviations used: $\mathrm{L} / *=$ Lepcha; $\mathrm{N}=$ Nepali]

\begin{tabular}{|c|c|c|}
\hline Disease & Symptom & Ethno-veterinary formulations \\
\hline $\begin{array}{l}\text { Re-biknet }(\mathbf{L}) \\
\text { Prevalent diseases in } \\
\text { high altitude. } \\
\text { yaks \& sheep; } \\
3600 \mathrm{~m} \text { and above }\end{array}$ & $\begin{array}{l}\text { Fever, doesn't feed, } \\
\text { swelling of skin, gives a } \\
\text { sound when rubbed, } \\
\text { cattle may die within } 10 \\
\text { - } 15 \text { days; the disease } \\
\text { appear twice a year } \\
\text { during Summer }\end{array}$ & $\begin{array}{l}\text { The whole plant of Cissus elongata Roxb. [Vitaceae] (Tundo- } \\
\text { rik }^{*} \text { ) is crushed into paste and given orally once in a day and } \\
\text { applied externally on the body for } 2-3 \text { days till it gets cured } \\
\text { Restrictions: Avoid leafy green fodders. }\end{array}$ \\
\hline $\begin{array}{l}\text { Somyang-ro (L) } \\
\text { Summer cattle fever } \\
\text { of cows, buffalos, etc. }\end{array}$ & $\begin{array}{l}\text { Fever, irritation in entire } \\
\text { body, can't stand properly } \\
\text { and low appetite }\end{array}$ & $\begin{array}{l}\text { Massage with one year old Zea mays L. [Poaceae] (Kutshung*) } \\
\text { fruit stick and feeding for two -three dry fruit leaves of Zea } \\
\text { mays or dry paddy straw soaking in lukewarm water, } 2-3 \text { times } \\
\text { a day. } \\
\quad \text { or } \\
\text { The hearth mud and salt is packed inside the leaf of Cucumis } \\
\text { sativus L. [Cucurbitaceae] (Tungut*) and given twice a day for } 2 \\
\text { - } 3 \text { days. } \\
\text { Restrictions: Green fodder and cold water not to be given for } \\
\text { some days }\end{array}$ \\
\hline $\begin{array}{l}\text { Sudek-krim }(\mathbf{L}) \\
\text { Vyagutey }(\mathbf{N}) \\
\text { Swollen throats of } \\
\text { cows and buffalos }\end{array}$ & $\begin{array}{l}\text { Swollen throat, Pain } \\
\text { while feeding }\end{array}$ & $\begin{array}{l}\text { Seed paste of Dioscorea deltoidea Wall. ex Griseb. } \\
\text { [Dioscoreaceae] (Kusok*) is applied externally on swollen throat } \\
\text { and } 50 \text { - } 60 \text { gm is given orally once in day for } 3 \text { - } 5 \text { days. } \\
\text { Or } \\
\text { Paste of Capsicum frutescens L. [Solanaceae] (Rani-Sunkar*) is } \\
\text { applied externally on the affected area. } \\
\quad \text { Or } \\
\text { Flintstone (sudher long*) is rubbed to make a thick paste and is } \\
\text { applied externally. } \\
\text { Note: If the affected calves are not cured in 2-3 days then the } \\
\text { result is death. }\end{array}$ \\
\hline $\begin{array}{l}\text { Vee-jyit }(\mathbf{L}) \\
\text { Lomutey }(\mathbf{N}) \\
\text { Blood in urine of } \\
\text { cows, buffalos, etc. }\end{array}$ & $\begin{array}{l}\text { Frequent urination with } \\
\text { blood at an interval of } 15 \\
-20 \text { minutes with pain }\end{array}$ & $\begin{array}{l}\text { The decoction of root, bark or twig of Alsophila gigantea Wall. } \\
\text { ex Hook. [Cyatheaceae] }\left(\boldsymbol{P a} \boldsymbol{a}^{\prime} \mathbf{j i k} \boldsymbol{k}^{*}\right) * \text { is given orally for } 4-5 \text { times } \\
\text { once a day. } \\
\quad \text { Or } \\
\text { Meat of bat to be given three times a day. } \\
\text { Or } \\
\text { Decoction of } 100 \text { gm of Sugar mix with } 30 \mathrm{gm} \text { of Red /yellow } \\
\text { soil with little amount of water is given to the cattle. }\end{array}$ \\
\hline $\begin{array}{l}\text { Tabok bril }(\mathbf{L}) \\
\text { Indigestion/ stomach } \\
\text { disorder of cows, } \\
\text { buffalos, etc. }\end{array}$ & $\begin{array}{l}\text { Loss of appetite and } \\
\text { weakness }\end{array}$ & $\begin{array}{l}\text { The mixture or individual fruits of Tetradium fraxinifolium } \\
\text { (Hook.) T.G.Hartley [Rutaceae] (Tundorik*), Litsea cubeba } \\
\text { (Lour.) Pers. [Lauraceae] (Kunndu*) and Tetrataenium wallichii } \\
\text { (DC.) Manden. [Apiaceae] (Syamben*) are given twice a day till } \\
\text { cured. }\end{array}$ \\
\hline $\begin{array}{l}\text { Nyin- hru (L) } \\
\text { Thunelo }(\mathbf{N}) \\
\text { Udder swelling in } \\
\text { cows, buffalos, } \\
\text { goats, etc. }\end{array}$ & $\begin{array}{l}\text { Swelling of udder due to } \\
\text { thickening of milk, } \\
\text { fever, reduced lactation }\end{array}$ & $\begin{array}{l}\left.\text { The spine of porcupine (Bokruk } \boldsymbol{k}^{*}\right) \text { is made rolled on swelled } \\
\text { nipple and pressed inside when other normal nipples are kept tied. } \\
\text { The affected nipples are then allowed to let sucked by the calf } \\
\text { until thick yellowish, unpleasant odour milk released out } \\
\text { completely. }\end{array}$ \\
\hline $\begin{array}{l}\text { Bik-dulot (L) } \\
\text { Loose motion / } \\
\text { Diarrhoea. } \\
\text { Cows, buffalos, etc. }\end{array}$ & $\begin{array}{l}\text { Watery stool, whole } \\
\text { body, loss of weight }\end{array}$ & $\begin{array}{l}\text { The decoction of leaves of castrated female plant of Cannabis } \\
\text { sativa L. [Cannabaceae] (Ganjoh*) is given orally twice a day } \\
\text { for } 1-2 \text { days depending on the condition. } \\
\text { Or } \\
\text { The decoction of matured fruits of Rhus chinensis Mill. } \\
\text { [Anacardiaceae] (Tunghril*) is given twice daily for } 1-2 \text { days. } \\
\quad \text { Or } \\
\text { The bark of Mangifera indica L. [Anacardiaceae] ( } \text { Ambi*) and } \\
\text { Psidium guajava L. [Myrtaceae] (Sungzampot) } 100-150 \text { gms is } \\
\text { crushed to paste with stones and fed to cattle and goats once in a } \\
\text { day till recovery. }\end{array}$ \\
\hline
\end{tabular}


76 Ethno-veterinary practices by Lepchas in DTRA

\begin{tabular}{|c|c|c|}
\hline Disease & Symptom & Ethno-veterinary formulations \\
\hline $\begin{array}{l}\text { Kuptyol-hlu (L) } \\
\text { Difficulty in } \\
\text { expulsion of placenta } \\
\text { in cows, buffalos, } \\
\text { goats, etc. }\end{array}$ & $\begin{array}{l}\text { Impatient, mooing for } \\
\text { longer period, placenta } \\
\text { not coming out easily } \\
\text { during birth }\end{array}$ & $\begin{array}{l}\text { The leaves of Hellenia speciosa (J.Koenig) S.R.Dutta } \\
\text { [Costaceae] (ankhley*/Beth lauri) } \\
\text { Or } \\
\text { Leaves of sugarcane [Saccharum officinarum L. of Poaceae] } \\
\quad \text { Or } \\
\text { Leaves of Zea mays L. [Poaceae] is given to eat and it works } \\
\text { within two hours. }\end{array}$ \\
\hline $\begin{array}{l}\text { Sya'k (L) } \\
\text { Ticks/ mites } \\
\text { infestation in majority } \\
\text { of cattle }\end{array}$ & $\begin{array}{l}\text { Loss of weight, wounds } \\
\text { in skin, etching }\end{array}$ & $\begin{array}{l}\text { Decoction of } 2-3 \text { litre in the ratio of 6:3:1 of Nicotiana } \\
\text { tobacum L. [Solanaceae] (Tongkun-nyom *), Lyonia ovalifolia } \\
\text { (Wall.) Drude [Ericaceae] (Sunglen nyom *) and common salt in } \\
250-300 \mathrm{ml} \text { of water is applied externally on the whole body. }\end{array}$ \\
\hline $\begin{array}{l}\text { Bruttzyak (L) } \\
\text { Skin diseases in } \\
\text { majority of livestock }\end{array}$ & $\begin{array}{l}\text { Irritation on skin, scar } \\
\text { formations, loss of body } \\
\text { hair }\end{array}$ & $\begin{array}{l}\text { Paste of } 4-5 \text { fruits of Litsea cubeba (Lour.) Pers. [Lauraceae] } \\
(\text { Kunndu*) dissolved in half a cup of lukewarm water and give } \\
\text { orally twice a day for early treatment and doses can be increased } \\
\text { if it is mature. Application of root paste of Acorus calamus L. } \\
\text { [Acoraceae] (Ruklop*) or tender shoots of Lyonia ovalifolia } \\
\text { (Wall.) Drude [Ericaceae] (Tuksol-kung*) would be more } \\
\text { effective. } \\
\quad \text { Or } \\
10-20 \text { gm leafy shoot of Tetrastigma serrulatum (Roxb.) } \\
\text { Planch. [Vitaceae] (Tundo-rik*) are crushed and mix in } 200 \mathrm{ml} \\
\text { of water, given orally once in a day, for } 3-4 \text { days in the } \\
\text { treatment of dermatitis in cattle. It can also apply externally on } \\
\text { the whole body or on parts of the body. } \\
\text { Caution: For pigs, refrain from giving oral dose of Litsea cubeba } \\
(\text { Kundu*), it may result to instant death. }\end{array}$ \\
\hline $\begin{array}{l}\text { Bongkur nyet }(\mathbf{L}) / \\
\text { Khuret }(\mathbf{N}) \\
\text { Foot and mouth } \\
\text { disease in cows, } \\
\text { buffaloes, pigs, goats }\end{array}$ & $\begin{array}{l}\text { Excessive salivation, } \\
\text { fever, vesicular lesions in } \\
\text { hoof mouth and tongue }\end{array}$ & $\begin{array}{l}\text { Few leaves of Cucumis sativus L. [Cucurbitaceae] (Suret*), and } \\
\text { of of Cucurbita pepo L. [Cucurbitaceae] ( Tungut*), red mud } \\
\text { and } 1 \text { to } 2 \text { big spoon of salt are mix together and administered } \\
\text { orally to the sick cattle. } \\
\text { Or } \\
8-10 \text { gm of the termites/white ant's (Tukfil*) left castle mud } \\
\text { is given by mixing with } 200-250 \text { gm of maize flour thrice a day } \\
\text { for seven days and the mixture of Curcuma longa L. } \\
\text { [Zingiberaceae] (Munga*) rhizome (turmeric) powder, edible oil, } \\
\text { and charcoal powder are applied externally. } \\
\quad \text { Or } \\
10 \text { to } 20 \text { gm of paste of Capsicum frutescens L. [Solanaceae] } \\
\text { (Runi-sungkar*) is externally applied twice in a day and feeding } \\
\text { of } 200-250 \text { gm Fagopyrum esculentum Moench [Polygonaceae] } \\
\text { (Kurrhu*) seeds along with the food till it cures. } \\
\quad \text { Or } \\
\text { The leaves of Nyctanthes arbor-tristis L. (Oleaceae), whole plant } \\
\text { of Swertia chirayita (Roxb.) H.Karst. [Gentianaceae] } \\
\text { (Rungken*) leaves of Azadirachta indica A.Juss. [Meliaceae] } \\
\text { (Nimpati) are crushed together in half litre of water and given } \\
\text { orally once in a day till recovery } \\
\text { Restrictions: Avoid green leafy fodders and salt. } \\
\quad \text { Or } \\
\text { A spoon full honey of Apis mellifera (EE-thu*) is mixed } \\
\text { with fodder and administered to cure mouth \& foot } \\
\text { disease. }\end{array}$ \\
\hline $\begin{array}{l}\text { Khimmyung (L) } \\
\text { Rabies in cattle, dogs, } \\
\text { cows, pigs, goats }\end{array}$ & $\begin{array}{l}\text { Fever, sour throats, } \\
\text { vomiting, impatient, } \\
\text { unusual mooing and } \\
\text { discomfort feelings }\end{array}$ & $\begin{array}{l}\text { The bark of Betula cylindrostachya [Betulaceae] (Sungli-kung*) } \\
\text { and seeds of Datura stramonium L. [Solanaceae] are crushed into } \\
\text { paste with } 500 \mathrm{ml} \text { of water and given orally to livestock. The } \\
\text { disease is caused by the bites of mad dog. } \\
\text { Or } \\
\text { The fruits of Datura stramonium, root-stock of Smilax fulgen } \\
\text { aspera ferox Wall. ex Kunth [Smilacaceae], whole plant of } \\
\text { Equisetum diffusum D.Don [Equisetaceae], Tectaria coadunata } \\
\text { (J.Sm.) C.Chr. [Polypodiaceae], rhizome of Curcuma caesia }\end{array}$ \\
\hline
\end{tabular}




\begin{tabular}{|c|c|c|}
\hline Disease & Symptom & Ethno-veterinary formulations \\
\hline & & $\begin{array}{l}\text { Roxb. [Zingiberaceae], root of Calotropis procera (Aiton) } \\
\text { W.T.Aiton [Apocynaceae] and bark of Betula cylindrostachya, } \\
\text { are crushed into a paste in } 200 \mathrm{ml} \text { of water and given orally twice } \\
\text { a day for } 7-8 \text { days till recovery. }\end{array}$ \\
\hline $\begin{array}{l}\text { Moh }(\mathbf{L}) \\
\text { Non-accidental cuts } \\
\text { \& wounds in Almost } \\
\text { all cattle. }\end{array}$ & $\begin{array}{l}\text { Appearance of unusual } \\
\text { spots and formation of } \\
\text { pus in the skins and } \\
\text { other parts of body }\end{array}$ & $\begin{array}{l}\text { 10-12 leaves of Ageratina adenophora (Spreng.) R.M.King \& } \\
\text { H.Rob. [Asteraceae] (Vongnokbu*) is crushed into paste and } \\
\text { applied on wounds of cattle and goats once in a day till recovery. } \\
\text { Or } \\
\text { About } 50 \text { gm of ashes (Purusor*) of any wood, rhizome-powder } \\
\text { of Curcuma longa (Munga } * \text { ) and few ml of mustard oil are } \\
\text { mixed together and applied on the infected areas till recovery. } \\
\text { Or } \\
\text { The black powder of dry-battery is mixed with one spoonful of } \\
\text { mustard oil and applied on the wounds (gare ghau) once daily till } \\
\text { recovery in cattle. It protects from further infections. }\end{array}$ \\
\hline $\begin{array}{l}\text { Ateth- haal }(\mathbf{L}) \\
\text { Bone-fracture in } \\
\text { cows, goats, buffalos, } \\
\text { pigs }\end{array}$ & $\begin{array}{l}\text { Fracture of breaking of } \\
\text { bones, unusual mooing, } \\
\text { appearance or } \\
\text { accumulation of blood at } \\
\text { affected area }\end{array}$ & $\begin{array}{l}\text { About } 50 \text { gm of bark of Machilus odoratissima Nees [Lauraceae] } \\
\text { (Run-kung*), 50 gm of stem of Plumbago indica L. } \\
\text { [Plumbaginaceae], } 40 \text { gm of raw rhizome of Curcuma longa } \\
\text { (Munga } * \text { ), } 50 \text { gm of bark of Acer campbellii Hook.f. \& Thomson } \\
\text { ex Hiern [Aceraceae] (Yali*), } 50 \text { gm of rhizome of Kaempferia } \\
\text { galanga L. [Zingiberaceae] (Rebireep*), } 5-6 \text { leaves of Cissus } \\
\text { quadrangularis L. [Vitaceae], } \\
60-70 \text { gm of red-soil, } 2 \text { spoonful of common salt, and } 5-10 \text { gm } \\
\text { of slake lime are crushed into a paste, mix in } 1 \text { litre of water and } \\
\text { then applied on the affected areas. The affected areas should be } \\
\text { properly tied with the bandage, taking support of bamboo-slips and } \\
\text { needs to replace it after } 20 \text { days. }\end{array}$ \\
\hline $\begin{array}{l}\text { Lhheng-kok (L) } \\
\text { Cough in goats, dogs, } \\
\text { cows, buffalos }\end{array}$ & $\begin{array}{l}\text { Increase rate of } \\
\text { respiratory actions, } \\
\text { swelling and discomfort } \\
\text { in stomach, frequent } \\
\text { coughing, purulent nasal } \\
\text { discharges }\end{array}$ & $\begin{array}{l}500 \text { gm of powdered rice or wheat, } 100 \text { gm of Himalayan black } \\
\text { salt and } 70 \text { gm of Potash-alum (fitkari) are mixed, made a paste } \\
\text { and } 1 \text { litre of water is added to it and given orally three times a day } \\
\text { for } 3-4 \text { days in cough in cattle. }\end{array}$ \\
\hline $\begin{array}{l}\text { Tubok-hreng dok (L) } \\
\text { stomach problems } \\
\text { cows, goats, buffalos }\end{array}$ & $\begin{array}{l}\text { Enlargement of stomach, } \\
\text { frequent evacuation of } \\
\text { watery faeces; may contain } \\
\text { blood and mucus with } \\
\text { unpleasant ant odour }\end{array}$ & $\begin{array}{l}50 \text { gm of the Himalayan black salt is heated on the oven and } \\
\text { applied on the } \\
\text { affected areas (abdomen) for three consecutive days, preferably in } \\
\text { the morning or in afternoon in stomachic (or stomach enlargement) }\end{array}$ \\
\hline
\end{tabular}

\section{DISCUSSION}

In Sikkim, the majority of Lepcha primitive tribe lives in Dzongu Tribal Reserve Area (DTRA), an officially demarcated reserved area by Maharaja of Sikkim for Lepcha tribal community. The practice of age old traditional methods for the treatment of livestock diseases has been evolved and inherited through the generations since time immemorial and was maintained by the folk healers (Moandhok). Apart from the basic studies by Sharma \& Sharma (2010) and Bharati \& Sharma (2010), no extensive study has been carried out in respect to ethnoveterinary and its formulation Sikkim in general and DTRA in particular. Present ethno-veterinary exploration in DTRA during 2013 to 2017 led to consultation of 159 ethno-medicinal plant practitioners. A total of 11 prominent/ prevalent livestock diseases has been identified from the study area. The common livestock ailments in the area are blood with urine, diarrhoea, dysentery, bone fracture, wounds, foot-mouth diseases, udder infections, skin diseases, delayed expulsion of the placenta, fever, etc. (Plate-I. E). Altogether 39 plant species of EVM importance, under 23 families have been recorded from the DTRA. These plants are Acer campbellii Hook.f. \& Thomson ex Hiern (Aceraceae), Acorus calamus L. (Acoraceae) [Plate-I. B], Ageratina adenophora (Spreng.) R.M.King \& H.Rob. (Asteraceae), Alsophila gigantea Wall. ex Hook. (Cyatheaceae), Azadirachta indica A.Juss. (Meliaceae), Betula cylindrostachya Lindl. ex Wall. (Betulaceae), Calotropis procera (Aiton) W.T.Aiton (Apocynaceae), Capsicum frutescens L. (Solanaceae). Cannabis sativa L. 
78 Ethno-veterinary practices by Lepchas in DTRA
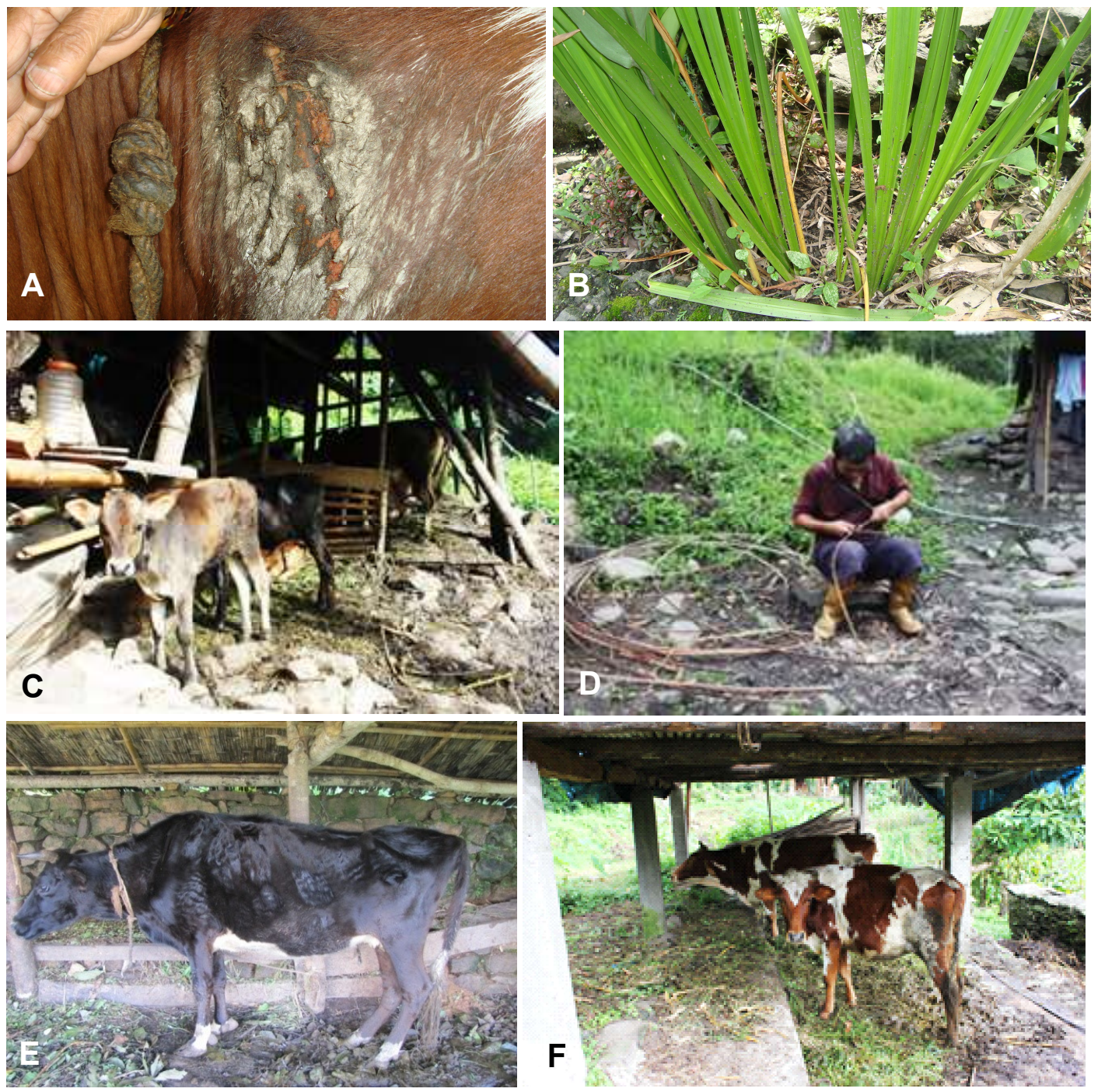

PLATE - I. Cattle and cattle-shdes in DTRA, Sikkim: A. Skin infection in cow; B. Acorus calamus, - commonly used plant in EVM; C. A traditional cowshed at Lower Dzongu; D. A local man is in the process of constructing cowshed using local rattans at Breng-Katam village; E. A cow suffering with blood-urine disease; F. A cowshed constructed with government assistance

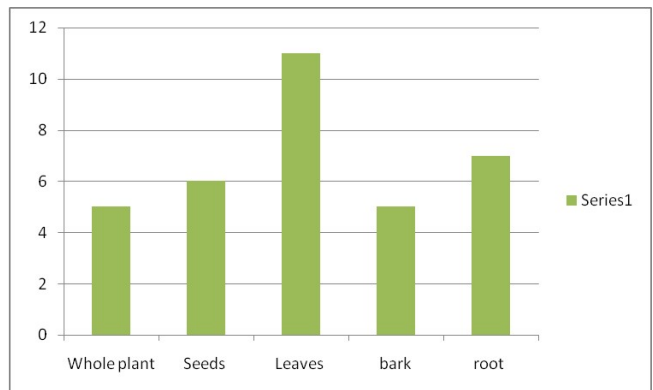

Figure 2. Usages of plant parts in preparation of ethno-veterinary formulations 
(Cannabaceae), Cissus elongata Roxb. (Vitaceae), Cissus quadrangularis L. (Vitaceae), Cucumis sativus L. (Cucurbitaceae), Curcuma caesia Roxb. (Zingiberaceae), Cucurbita pepo L. (Cucurbitaceae) Curcuma longa L. (Zingiberaceae), Hellenia speciosa (J.Koenig) S.R.Dutta (Costaceae), Datura stramonium L. (Solanaceae), Dioscorea deltoidea Wall. ex Griseb. (Dioscoreaceae), Equisetum diffusum D.Don (Equisetaceae), Fagopyrum esculentum Moench (Polygonaceae), Kaempferia galanga L. (Zingiberaceae), Litsea cubeba (Lour.) Pers. (Lauraceae), Lyonia ovalifolia (Wall.) Drude (Ericaceae), Machilus odoratissima Nees (Lauraceae), Mangifera indica L. (Anacardiaceae), Nicotiana tabacum L. (Solanaceae), Nyctanthes arbor-tristis L. (Oleaceae), Plumbago indica L. (Plumbaginaceae), Psidium guajava L. (Myrtaceae), Rhus cbinensis Mill. (Anacardiaceae), Saccharm officinarum L. (Poaceae), Saccharum officinarum L. (Poaceae), Smilax ferox Wall. ex Kunth (Smilacaceae), Swertia chirayita (Roxb.) H.Karst. (Gentianaceae), Tetradium fraxinifolium (Hook.) T.G.Hartley (Rutaceae), Tetrataenium wallichii (DC.) Manden. (Apiaceae), Tetrastigma serrulatum (Roxb.) Planch. (Vitaceae) Tectaria coadunata (J.Sm.) C.Chr. (Polypodiaceae), and Zea mays L. (Poaceae).

The study further revealed that apart from whole plants, the roots, seeds, flowers, barks, and leaves are being used in larger extent for the preparation of ethno-veterinary formulations (Figure 2). Apart from plants some other materials are also used in EVM, like gravels, claymud, wild-honey, black-salt, charcoal, slake limes, etc. as part of combinations for increasing the efficacy of their traditional drugs (Table 1). These materials are easily/ readily available within the territory of DTRA.

During the study, it was also realized that in order to improve the health of their livestock, the local people need to take care on the better maintenance of ghausalas (= cow-shades) (Plate-I. F).

The study further confirmed that the traditional healing practice is the lone alternative to modern medicines form of improvement in health of the cattle in the region.

The study further emphasized on conservation of ethno-veterinary knowledge which are in verge of vanishing due to several factors including ignorance, road connectivity, major developmental activities, influx of people from outside, etc. The local tribal people of DTRA are directly or indirectly depended on ethno-veterinary forms of livestock healing in many inaccessible areas such as Sakyong-Pentong, Lungthem, Lingaya, Rwong, Lungtyang, Breng katam and in other fringe areas. (Plate-I. C \& D). Therefore, the documentation of EVM practice and its formulations shall ensure the conservation of local traditional knowledge and for better resource management in the region in near future. It would be possible to pinpoint to specific individuals or groups as originators if a remedy turns out to be so valuable that patency issues arise (Sindhu et al. 2015; Lepcha 2014; Pradhan \& Mishra 2018). The knowledge on herbal formulations being applied on treatment of animals needs further investigation in filing for Intellectual Property Right (IPR) for the benefit of the livestock's holders and other EVM practitioners.

\section{CONCLUSION}

Dzongu Tribal Reserve Area (DTRA) is rich in its heritage of folk healers having enormous knowledge on the uses of plant resources in Ethno-veterinary practices. Apart from the basic studies by Sharma \& Sharma (2010) and Bharati \& Sharma (2010), no other extensive study has been carried out in respect to ethno-veterinary and its formulations in Sikkim in general and DTRA in particular. Livestock is an integral part of people of DTRA and apart from the allopathic medicines, they still rely on ethno-veterinary practices for the treatment of their livestock. But, the number of folk-healers are reducing fast endangering the traditional heritage. It is high time to explore all such traditional knowledge from Sikkim in general and DTRA in particular before all these are lost. 


\section{Acknowledgements}

The authors would like to thank all the livestock herders, Moandhoks (key informants) of DTRA for their cordial support during the survey. Also, they would like to extend gratitude to Sr. Officials from Department of Science \& Technology, Govt. of India and Sikkim State Council of Science \& Technology, Deorali, Gangtok, for all means of support extended to them during the study.

\section{LITERATURE CITED}

Agura, S. 2014. Analysis of Land cover changes in Drongu, Sikekim Identify how land cover has changed in accordance with social changes. MLA-EP, LA-221 Final Paper.

Ahmad, S.; Gangoo, S.; Sultan, S.M. \& Dar, M.D. 2016. Ethnoveterinary Practices and Use of Herbal Medicine by Pastoralists of Himalaya: A Review. Annals of Biology 32 (2): $260-268$.

Balaji, S.N. \& Chakravarthi, V.P. 2010. Ethnoveterinary Practices in India - A Review. Veterinary World 3(12): $549-551$.

Bennet, S.R. 1983. Ethnobotanical studies in Sikkim. Indian Forester 109 (7): 477 - 481.

Bharati, K.A. \& Sharma, B.L. 2010. Some ethnoveterinary plant records of Sikkim Himalaya, Indian Journal of Traditional knowledge, 9(2): $344-346$.

Bhasin, V. 2011. Settlements and Land-Use Patterns in the Lepcha Reserve-Drongu Zone in the Sikeim

Biswas, K. 1956. Common medicinal plants of Darjeeling and the Sikkim Himalayas. West Bengal Government Press, Alipore, Kolkata.

Das, A.P. \& Pandey, A.K. 2007. Advances in Ethnobotany. Bishen Singh Mahendra Pal Singh, Dehra Dun.

Das, S.K. \& Triparthy, H. 2009. Ethno-veterinary practices and socio-cultural values associated with animal husbandry in rural Sunderbans, West Bengal. Indian Journal of Traditional Knowledge 8(2): $201-205$.

Davidovic, Vesna; Joksimovic-Todorovic, Mirjana; Maksimovic, Zoran; Hristov, Slavca; Stankovic, Branislav \& Relic, Renata 2011. A review of plants used in ethnoveterinary medicine. Macedonian Journal of Animal Science, 1(2): 377 - 382.

Fonning, A.R, (1987), My Vanishing Tribe. Sterling Publishers Pvt. Ltd. New Delhi, India.

Forest Department 2010. Schemes and Policies Implemented from 1996 till 2010 Chapter II. Forests. Environment \& Wildlife Management Department, Government of Sikkim

Gorer, G. 1938. Himalayan Village: An Account of the Lepchas of Sikkim. M. Joseph Ltd., London.

Grierson, A. J. C. \& Long, D.G. (ed.) 1983, 1984, 1987. Flora of Bhutan. Vol. 1 parts 1 - 3, Edinburgh.

Grierson, A.J.C. \& Long, D.G., 1991, 1999, 2001. Flora of Bhutan, Vol. 2, Pts.1, 2 \& 3. RBG, Edinburgh

Gurung, B. 2003. The Medicinal Plants of the Sikkim Himalaya. Jasmine Bejoy Gurung. Maples, Chakung, West Sikkim.

Hooker, J.D. 1872-1897. The Flora of British India, Vols. 1-7. L. Reeve \& Co Ltd, Ashford, Kent. London.

Jain, S.K. \& Rao, R.R. 1977. A Hand Book of Field and Herbarium Technique. Today \& Tomorrow Publication, New Delhi. 
Jha, A.; Jha, S.; Suhag, V. \& Das, A. 2006. A preliminary survey of economically important plants of North Sikkim. Abstract, The $47^{\text {th }}$ Annual Meeting of Society and Economic Botany on Folk Botanical Wisdom: Towards Global Markets, Thailand (5 - 9 June, 2006), p. 32.

Köhler-Rollefson, I. \& Bräunig, J. 1998. Anthropological Veterinary: The Need for Indigenizing the Curriculum. Paper presented at the 9th AITVM Conference in Harare between 14th-18th September 1998, Harare, Zimbabwe.

Krishna, B \& Singh, S. 1987. Ethnobotanical observation in Sikkim. J. Econ. Tax. Bot. 9(1): 1 - 7.

Kumar, S., P. Singh and V. Singh. 1994. Ethnobatanical aspects of some arboreal and arborescent taxa of Sikkim. In: Gupta, B.K (eds), Higher plants of Indian Sub-continent 3: 164-166. B.S.M.P.S. Dehradun.

Lepcha, S.R. \& Das, A.P. 2011. Ethno-medicobotanical exploration along the international borders to Tibet Autonomous Region of China and the kingdom of B hutan with special reference to the Pangolakha Wildlife Sanctuary, East Sikkim. In Recent studies in Biodiversity and Traditional Knowledge in India. In: Ghosh, C. \& Das, A.P. (eds,), Gour College, Malda. \& Sarat Book House, Kolkta, Pp. 257 - 270.

Lepcha, S.R. 2011. Studies of Angiospermic flora of Alpine east Sikkim with Special reference to the Pangolakha Wildife Sanctuary. Ph.D. thesis, University of North Bengal, Siliguri.

Lepcha, S.R. 2014. Documentation of ethno-veterinary practices and its formulations of Sikkim, (unpublished research report). Sikkim State Council of Science \& technology, Vigyan Bhawan, Deorali, Gangtok Sikkim.

Maiti, D.; Chauhan, A.S. \& Maiti, G.G. 2003a. Ethnonbotanical notes on some unexploited plants used by Lepchas and Nepalese communities of North Sikkim. In: Singh, V. \& Jain, A.K. (eds.), Ethnobotany and Medicinal Plants of India and Nepal. Vol. 1. Scientific Publishers, Jodhpur, India. Pp. 325 - 332.

Maity, D.; Chauhan, A.S. \& Maiti, G.G. 2003b. Ethno-botanical notes on some unexplored medicinal plants used by Lepchas and Nepalese communities of North Sikkim. J. Econ. Taxon. Bot. 27(2): 325 - 332.

McCorkle, C.M. 1986 An Introduction to Ethnoveterinary Research and Development. Journal of Ethnobiology 6 (1): 129 - 149.

Morris, J. 1938. Living with Lepcha: A Book about the Sikkim Himalayas. William Heinemann Ltd., London.

Nair, M.N.; Balakrishnan, \& Rajneesh, S. 2011. Documentation and assessment of etbno-veterinary practices, - A strategy for Mainstreaming Local health traditions for sustainable veterinary care in India. Testing and validation of indigenous Knowledge, Compass Indigenous Development. Centre for Indian knowledge Systems, Chennai pp. 60 - 94.

Noltie,H.J. (ed) 1994, 2000. Flora of Bbutan Vol. 3 Parts I \& II, Royal Botanic Garden, Edinburg.

Pradhan, B.K. \& Badola, H.K. 2008. Ethnomedicinal plant use by Lepcha tribe of Dzongu valley, bordering Khangchendzonga Biosphere Reserve, in North Sikkim, India. Journal of Ethnobiology \& Ethnomedicine doi:10.1186/1746-4269-4-22.

Pradhan, S. \& Mishra, S. 2018. Ethnoveterinary practice: An alternative treatment approach in contemporary India. The Pharma Innovation Journal 7(9): 362 - 365.

Punniamurthy, N. 2010. Ethno-veterinary Medicine for Primary Health Care of Livestock. Heritage Amruth 6(3): 11 - 14.

Pushpangadan, P. \& Dan, V.M. 2011. Modern methods and strategies of bioprospecting of traditional knowledge and the issues related to beneft sharing. Ethnobotany 23: $1-20$. 
82 Ethno-veterinary practices by Lepchas in DTRA

Pushpangadan, P.; Ijinu, T.P. \& Dan, V.M. 2018. Evolution of Ethnopharmacology Research in India and their Bioprospecting Strategies. In: Das, A.P. \& Bera, S. (eds.), Plant Diversity in the Himalaya Hotspot Region. Vol. II. Bishen Singh Mahendra Pal Singh, Dehra Dun. ISBN: 978-81-211-0985-7. Pp. 787 - 806.

Rai, L.K. \& Sharma, E. 1994. Medicinal plants of Sikkim Himalaya: Status, Uses and Potential. Bishen Singh Mahendra Pal Singh, Dehra Dun.

Samant, S.S. \& Dhar, U. 1997. Diversity, endemism and economic potential of wild edible plants of Indian Himalaya. International Journal of Sustainable Development \& World Ecology 4: $179-191$.

Samant, S.S.; Dhar, U. \& Palni, L.M.S. 1998. Medicinal plants of Indian Himalaya: Diversity, Distribution, Potential Values. Gyanodaya Prakashan, Nainital.

Sharma, A. 2013. The Lepchas of Drongu Region in Sikkim (A Narrative of Cultural Heritage and Folklore). Intact Aryan Books International, New Delhi.

Sharma, T.P. \& Sharma, S. 2010. Medicinal Plants of Sikkim. Berthang, West Sikkim.

Sharma, U.K. 2012. Ethno-veterinary Plants of North East India. Bishen Singh \& Pal Singh, Dehra Dun.

Sindhu, Z.U.D.; Iqbal, Z.; Khan, M.N.; Jonsson, N.N. \& Siddique, M. 2010. Documentation of ethno-veterinary practices used for treatment of different ailments in selected a hilly area of Pakistan, 201x. Intn. J. Agric. Biol., 12: 353 - 358.

Sinha, G.P. \& Chauhan, A.S. 1997. Ethno-botanical Studies on the Lepchas of Sikkim. Himalayan Paryavaran 5(1): 60 - 63.

Srivastava, R.C. \& Kapaki, B.K. 1990. Resource survey of plants of potential economic value of Sikkim Himalaya. Bull. Medico Ethnobotany Res. 12 (1 - 2): 1 - 11.

Tamang, P. \& Lepcha, S.R. 2001. Studies of Medicinal Plants of Sikkim. (Unpublished Research Report), Sikkim State Council of Science \& Technology, Vigyan Bhawan, Deorali Gangtok, Sikkim.

www.plantsoftheworldonline.org

Yonzone, R.; Bhujel, R.B. \& Rai, S. 2012. Genetic resources, current ecological status and altitude wise distribution of medicinal plants diversity of Darjeeling Himalaya of West Bengal, India. Asian Pacific Journal of Tropical Biomedicine 2(1): 439 - 445. 